\title{
Design Student Examination Mark-sheet Management System for Lebanese French University (LFU
}

\author{
Chiai Al-Atroshi \\ Information Technology Department / Lebanese French University \\ chiai@lfu.edu.krg
}

\section{ARTICLE INFO}

\section{Article History:}

Received: 21/7/2018

Accepted: 10/9/2018

Published: Fall 2018

Doi:

10.25212/lfu.qzj.3.4.32

Keywords:

Software, Database, Application, SEMMS, LFU

\section{ABSTRACT}

In this paper, a custom student examination mark-sheet management system (SEMMS) is developed to overcome the problems that arise in the manual system, avoid errors while entering the data, and makes seeking information easier. The results show how useful this software is in helping LFU University and its student: 1) perform their work faster, create a better-looking diagram; 2) plan a good layout before implementing a real network; 3) keeping their information secure; and 4) make their management easier. The software provides an attractive environment where data about college students and employees can be handled easily.

\section{INTRODUCTION}

Computer applications have dramatically influenced in our social lives, including educational systems. Traditional methods need to be reconsidered and electronic and automatized examination systems be incorporated [1]. Thus, automatic examination systems became very beneficial in various academic fields in recent years [2]. In this article, the design and implementation of a comprehensive college/institute examination mark-sheet management system and user interface is provided to replace the current paper-based examination form. College staff are able to directly access all aspects of a student's academic. 


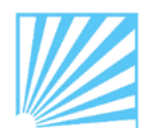

LF U

\section{QALAAI ZANIST SCIENTIFIC JOURNAL}

A Scientific Quarterly Refereed Journal Issued by Lebanese French University - Erbil, Kurdistan, Iraq

Vol. ( 3 ), Issue ( 4 ), Fall 2018

ISSN 2518-6566 (Online) - ISSN 2518-6558 (Print)

The design and implementation of the system is to provide service in institute and colleges. The system is to provide comprehensive student information system and user interface is to replace the current paper records. College Staff uploads students, teachers, subject results, and college notifications through a secure, online interface using computers and mobile devices. All data is thoroughly reviewed and validated on the server before actual record alteration occurs. All data is stored securely on MySQL database managed by the college Administrator. The system decreases paper work and time needed to access student records. Previously, college relied heavily on paper records for this initiative, which had its own disadvantages. This system provides a simple interface for the maintenance of student information. It can be used by educational institutes or colleges to maintain the records of students easily. Achieving this objective is difficult using a manual system as the information are scattered, can be redundant and collecting relevant information may be very time consuming. Our proposed system ensures to overcome these limitations. The paper focuses on presenting information in an easy and intelligible manner, which provides facilities like online registration and profile creation of students, examination marks monitoring, circular notifications, result viewing thus reducing paper work and automating the record generation process in an educational institution. There is an increasing trend for higher education institutions to be expected to monitor student records. This software generates reports on the results of research that considered the effect of attendance on student performance; surveyed planning students about attendance issues, shared the results with colleagues including agreement on a Departmental policy change, and assessed the approach academic staff should take towards poor attendance.

\section{Literature Review}

School administrative computer applications were developed in the late 1970s. In the early 1980s, several loose, non-integrated clerical designed had limited management support and data analysis capabilities [3]. During the initial stages, software development and usage aimed at improving the efficiency of school office activities. The use of computers and technologies in educational institution was to store student and personnel data [4]. The value of information management was recognized during the integration stages. Therefore, governments in developed 
countries initiated many projects to achieve efficient and effective school information systems. The focus was on the development of a standard system for as many schools as possible with maximum flexibility. The professional approach to systems design was not widespread at the time. In the 1990s, Information and communication technology (ICT) was increasingly used in the developing countries to collect educational data and streamline the educational systems [3]. believes that Management Information Systems (MIS) can provide administrators and teachers with the information required for informed planning, policy-making, and evaluation [5]. claimed that MIS has changed school management in the areas of leadership, decision making, workload, human resource management, communication, and planning [6]. These systems can assist a school head teacher in determining the goals of the school, formulating strategies, distributing resources, and evaluating staff performance as well as organization $[7,8]$. Indicates that the growing interest in MIS's and the trend toward [9].

\section{Methods and materials}

\section{System Analysis and Design}

The Design phase describes features and operations in detail, including database and software design, screen layouts and other aspects. Various types of design were made to develop this software, like Entity-relationship diagram (ERD) [10], Unified modeling language (UML) [11], etc. 


\section{QALAAI ZANIST SCIENTIFIC JOURNAL}

A Scientific Quarterly Refereed Journal Issued by Lebanese French University - Erbil, Kurdistan, Iraq

LF U

Vol. ( 3 ), Issue ( 4 ), Fall 2018

ISSN 2518-6566 (Online) - ISSN 2518-6558 (Print)

\section{Activity Diagram}

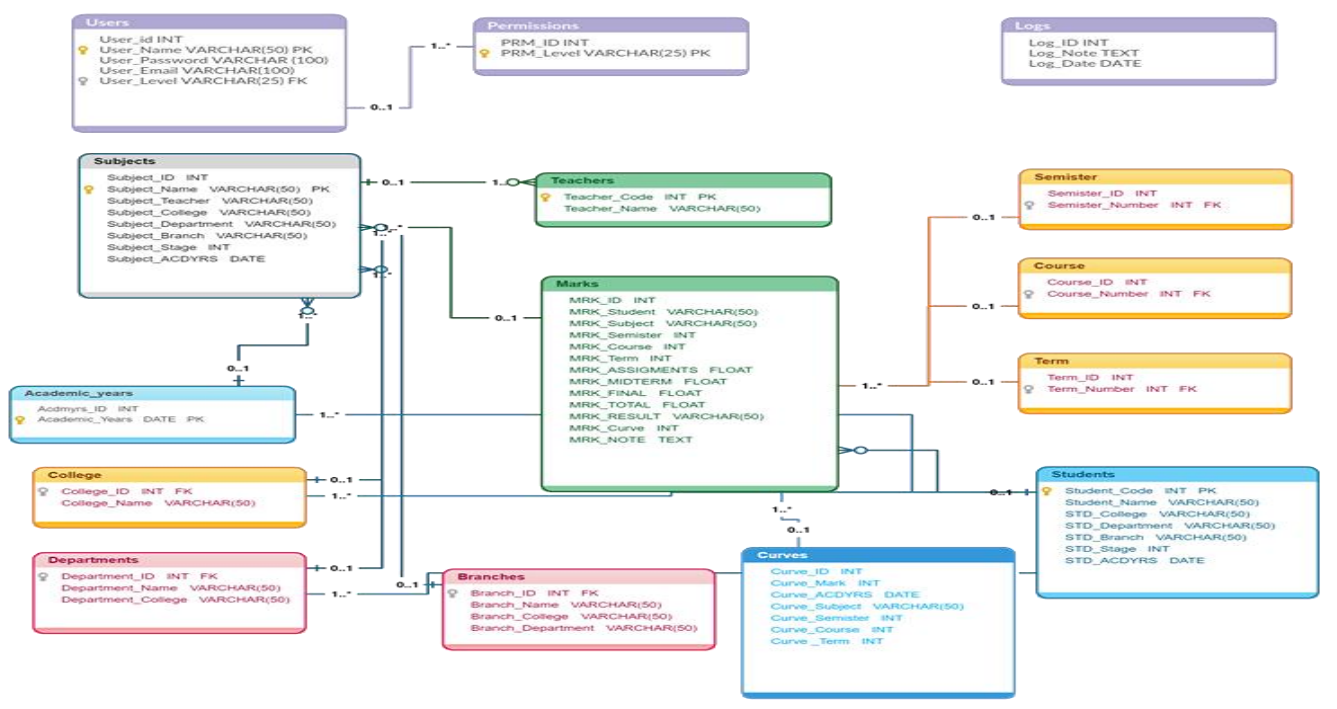

Figure (1): Relation between Tables and Connection between Database Elements

\section{Data Flow Diagram (DFD)}

A data-flow diagram is a graphical representation of the "flow" of data through an information system. DFDs can also be used for the visualization of data processing (structured design). On a DFD, data items flow from an external data source or an internal data store to an internal data store or an external data sink, via an internal process [12]. 


\section{QALAAI ZANIST SCIENTIFIC JOURNAL}

A Scientific Quarterly Refereed Journal Issued by Lebanese French University - Erbil, Kurdistan, Iraq

Vol. ( 3 ), Issue ( 4 ), Fall 2018

ISSN 2518-6566 (Online) - ISSN 2518-6558 (Print)

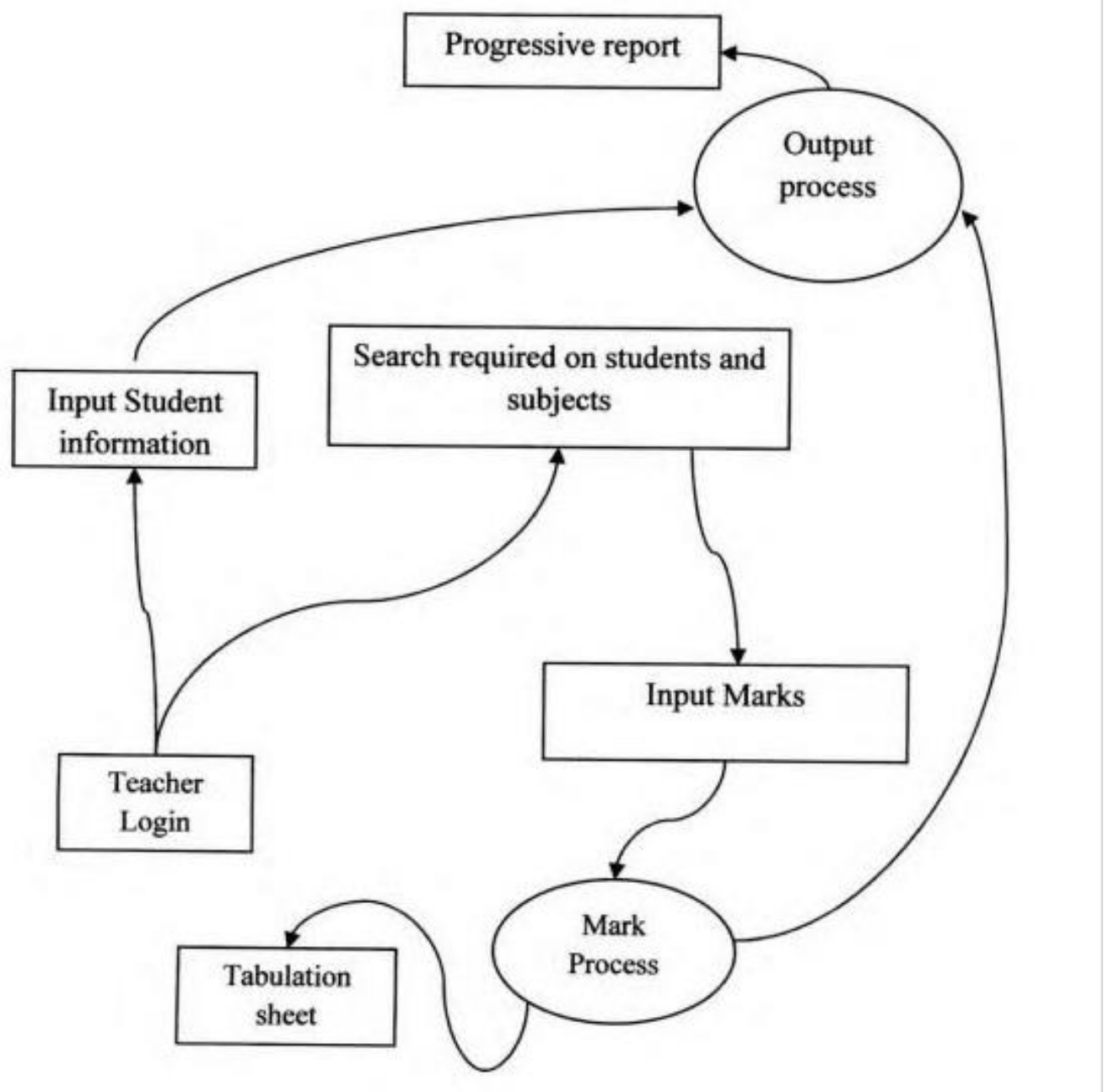

Figure (2): DFD of Proposed System

\section{System Architecture}

The College Mark-sheet Management System (CMMS) is composed of independent software components developed using different proprietary and nonproprietary web development tools. This design is based on Service-oriented Architecture (SOA). Using any modern browser, like Google Chrome, Firefox, 


\section{Iraq}

Vol. ( 3 ), Issue ( 4 ), Fall 2018

ISSN 2518-6566 (Online) - ISSN 2518-6558 (Print)

Opera, Safari, or IE10, the user can access the CMMS without installing any additional software. The System Administrator can add, edit, delete, and assign marks to student. The following information systems can be launched by the CMMS: Student Information Management System (SIMS), Teacher Information Management System (TIMS), Subjects Management System (SMS), and Marksheet Information Management System (MIMS). Through the links in the main page, authorized users can access the system webpages and respective databases hosted by different cloud service providers. The system architecture of CMMS is shown in Figure (3).

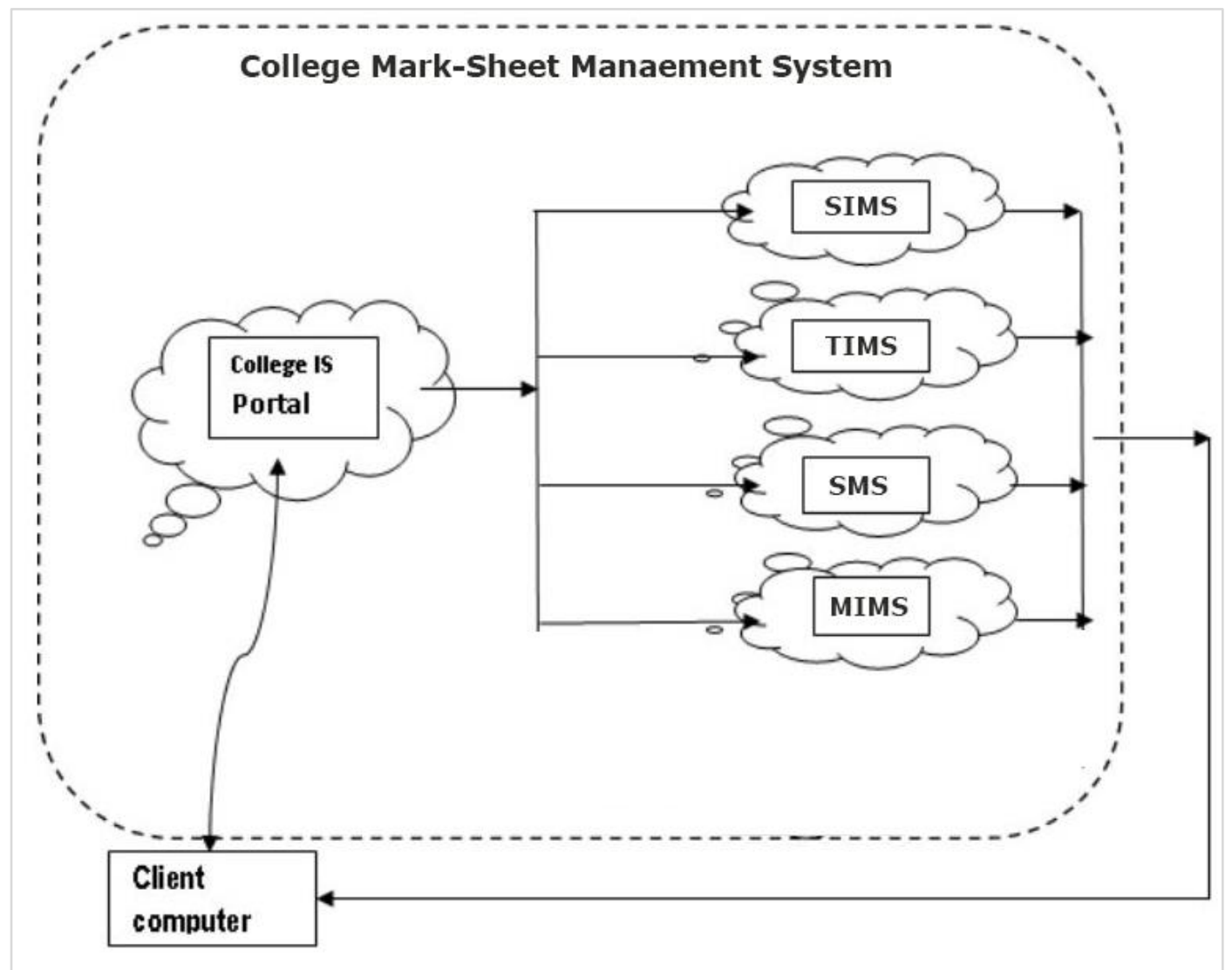

Figure (3): Proposed System Architecture 


\section{System Implementation}

\section{Introduction}

The system requirements and implementation toolset are presented in this chapter, where a user interacts with the implemented system through a demonstration test. Finally, the empirical outcomes are discussed.

\section{System Requirements}

The implemented system will be run as follows:

\subsection{No Need for Extra Hardware}

In the current system, computer laboratory facilities exit with internet line; that is why there is no need of extra computer or internet line.

\subsection{Software Interfaces}

Software is a general term for information that is recorded onto a medium. Most of the software on our computer comes in the form of programs. A program consists of instructions that tell the computer what to do, and how to behave. In this work, the following software are used as helping tools:
2.2.1 Microsoft Internet Explorer
2.2.2 Apache HTTP Server
2.2.3 HTTP
2.2.4 PHP
2.2.5 Macromedia Dreamweaver MX
2.2.6 MySQL
2.2.7 SQL
2.2.8 Cascading Style Sheets (CSS)

\section{Toolset}

The tools that are used for implementation range from programming and data manipulation languages to implementation tools, as outlined in Section (1.5.) as detailed below:

\subsection{PHP}

It is a widely used open source general-purpose scripting language suited for web development and can be embedded into HTML [13]. 


\section{QALAAI ZANIST SCIENTIFIC JOURNAL \\ A Scientific Quarterly Refereed Journal Issued by Lebanese French University - Erbil, Kurdistan, Iraq \\ LF U \\ Vol. ( 3 ), Issue ( 4 ), Fall 2018 \\ ISSN 2518-6566 (Online) - ISSN 2518-6558 (Print)}

\subsection{HTML}

It stands for Hypertext Markup Language used to create electronic documents (called pages) that are displayed on the World Wide Web (WWW). Each page contains a series of connections to other pages called hyperlinks. Most of the webpages seen on the Internet are written using a version of HTML code [14].

\subsection{Cascading Style Sheets (CSS)}

It is a style sheet language used for describing the presentation of a document written in a mark-up language, like HTML. The CSS is a cornerstone technology of the WWW, alongside HTML and JavaScript [15].

\subsection{MySQL}

It is a relational database management system (RDBMS), which has more than six million installations. MySQL stands for "My Structured Query Language". With its proven performance, reliability and ease-of-use, MySQL has become the leading database choice for web-based applications used by high profile web properties including Facebook, Twitter, YouTube, Yahoo! and many more. Oracle drives MySQL innovation, delivering new capabilities to power next generation web, cloud, mobile and embedded applications [16].

\subsection{Querying Language SQL}

It is a database computer language designed for managing data in RDBMS [17].

\subsection{Apache}

The Apache HTTP Server, commonly referred to as Apache is a web server notable for playing a key role in the initial growth of the WWW [18].

\section{Login}

\section{Results and Discussions}

Login is the first window that will appear when trying to enter this system as shown in Figure (4). It includes Username and Password related to the database that allow a permitted user to log in the system and then redirect them to the System Dashboard as shown in Figure (5). 


\section{QALAAI ZANIST SCIENTIFIC JOURNAL}

A Scientific Quarterly Refereed Journal Issued by Lebanese French University - Erbil, Kurdistan,

$$
\text { Iraq }
$$

LF U

Vol. ( 3 ), Issue ( 4 ), Fall 2018

ISSN 2518-6566 (Online) - ISSN 2518-6558 (Print)

Figure (4): Login Page

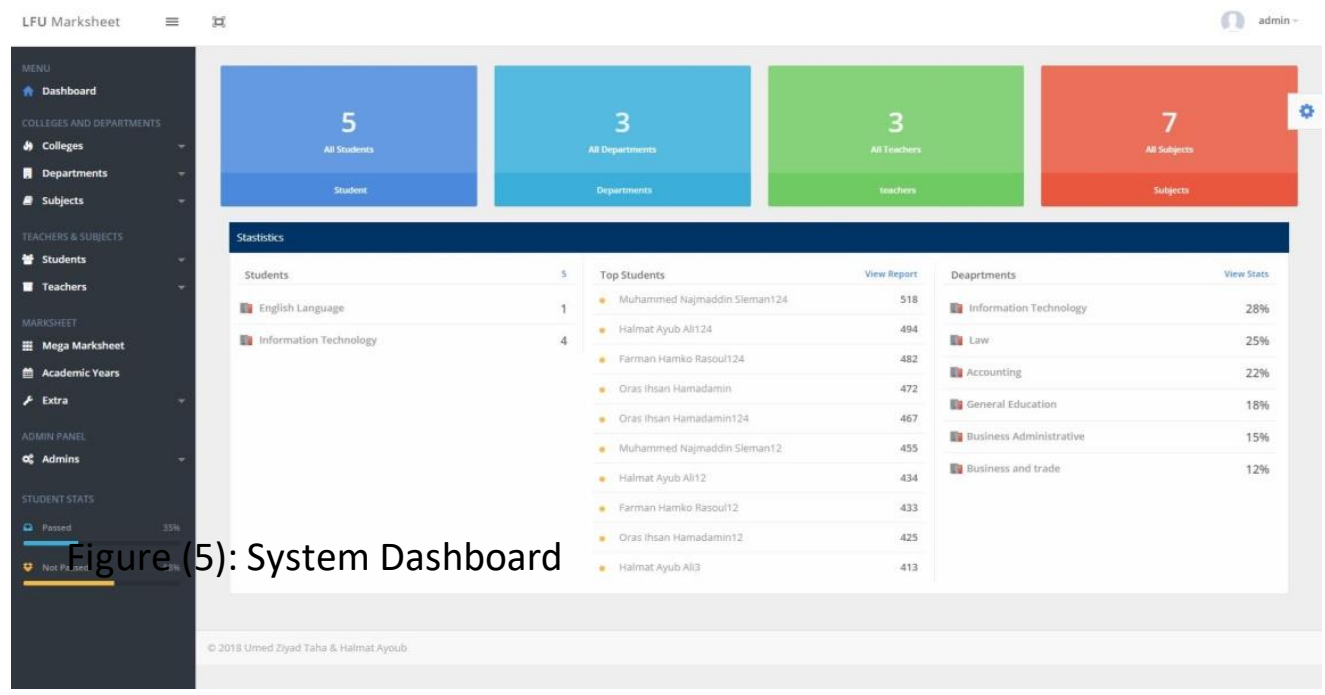

\section{Colleges}

The first step in this system is enter the college and department data and only the Administrator can manage or add colleges as shown in Figures (6) and (7) or print a result page, Figure (8).

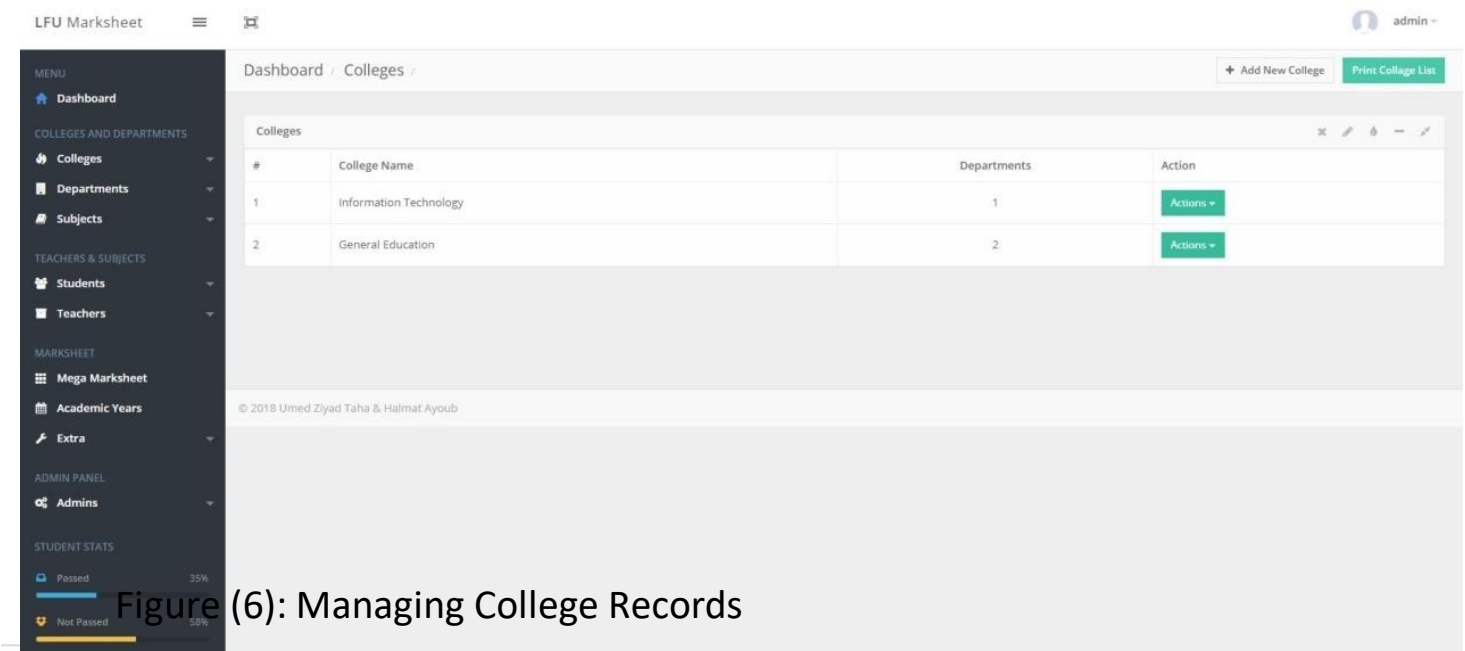




\section{QALAAI ZANIST SCIENTIFIC JOURNAL}

A Scientific Quarterly Refereed Journal Issued by Lebanese French University - Erbil, Kurdistan, Iraq

Figure (7): Adding New College

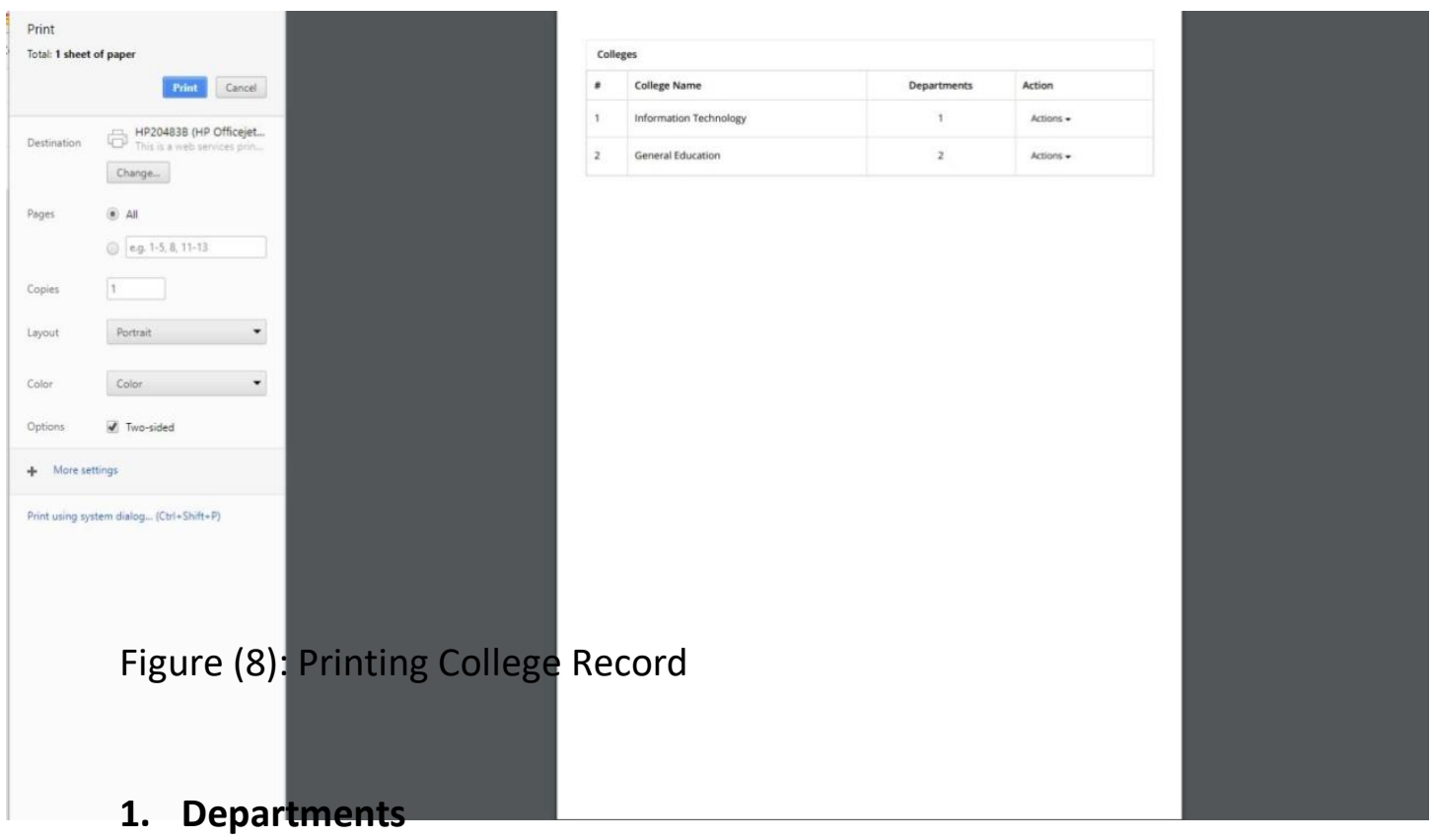




\section{QALAAI ZANIST SCIENTIFIC JOURNAL}

A Scientific Quarterly Refereed Journal Issued by Lebanese French University - Erbil, Kurdistan,

$$
\text { Iraq }
$$

LF U

Vol. ( 3 ), Issue ( 4 ), Fall 2018

ISSN 2518-6566 (Online) - ISSN 2518-6558 (Print)

Each college department has its own manager who can add, edit, delete, and print each department's data as demonstrated in Figure (9). A new department can be created by selecting Exist College as shown in Figure (10).
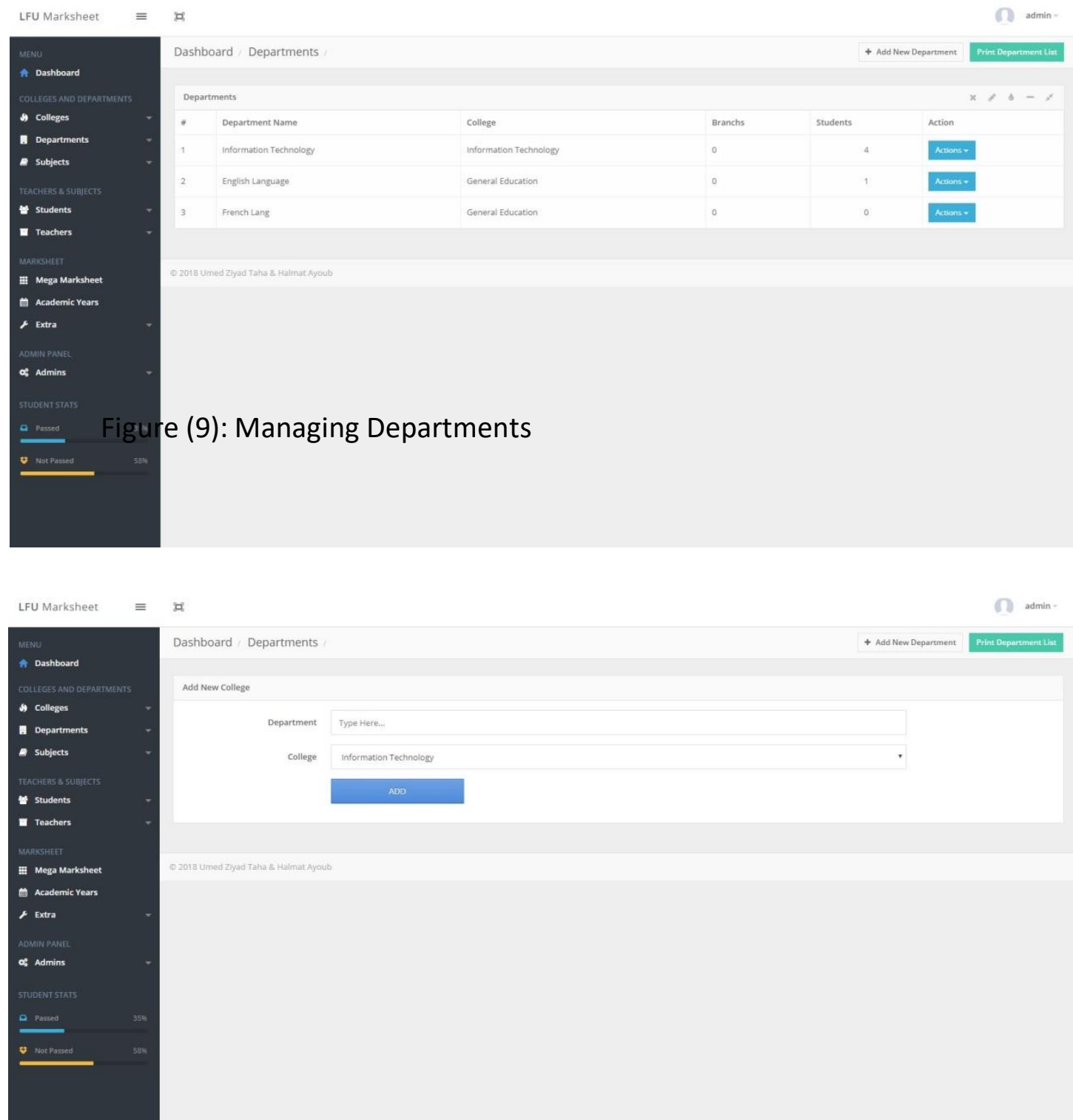


\section{QALAAI ZANIST SCIENTIFIC JOURNAL}

A Scientific Quarterly Refereed Journal Issued by Lebanese French University - Erbil, Kurdistan,

$$
\text { Iraq }
$$

Vol. ( 3 ), Issue ( 4 ), Fall 2018

ISSN 2518-6566 (Online) - ISSN 2518-6558 (Print)

Figure (10): Adding New Department

\section{Teachers}

Teachers can give a lecture to students in different departments and may have various subjects in different stages. Figure (11) shows a list of teachers and Figure (12) shows how the Administrator or Manager can add a new teacher.

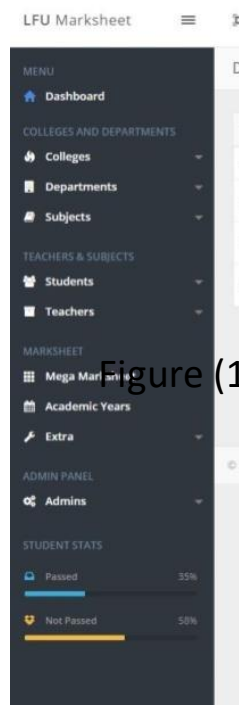

Dashboard Teachers

(11): Listing Teachers
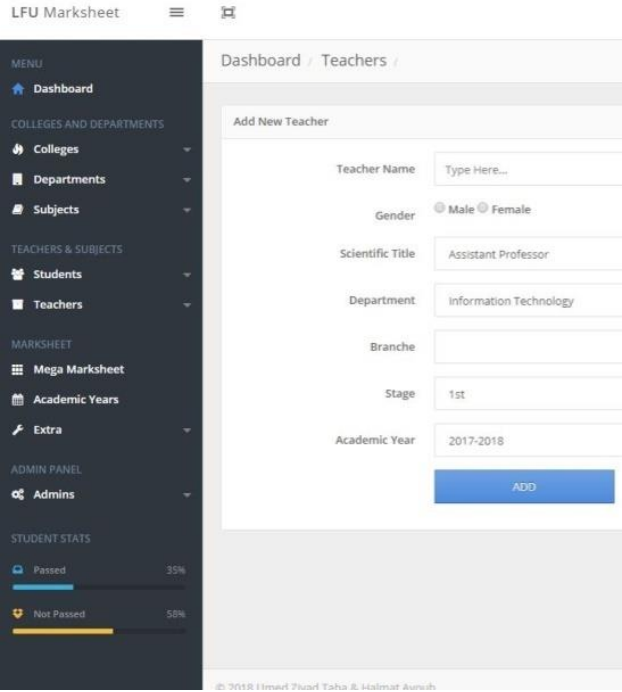


\section{QALAAI ZANIST SCIENTIFIC JOURNAL}

A Scientific Quarterly Refereed Journal Issued by Lebanese French University - Erbil, Kurdistan,

$$
\text { Iraq }
$$

Vol. ( 3 ), Issue ( 4 ), Fall 2018

ISSN 2518-6566 (Online) - ISSN 2518-6558 (Print)

Figure (12): Adding Teacher

\section{Subjects}

Each department has at least four stages and each stage as a variety of subjects. The Manager can add and edit the marks of each subject. Figure (13) shows the list of subjects and Figure (14) shows how the Manager can add a new subject.

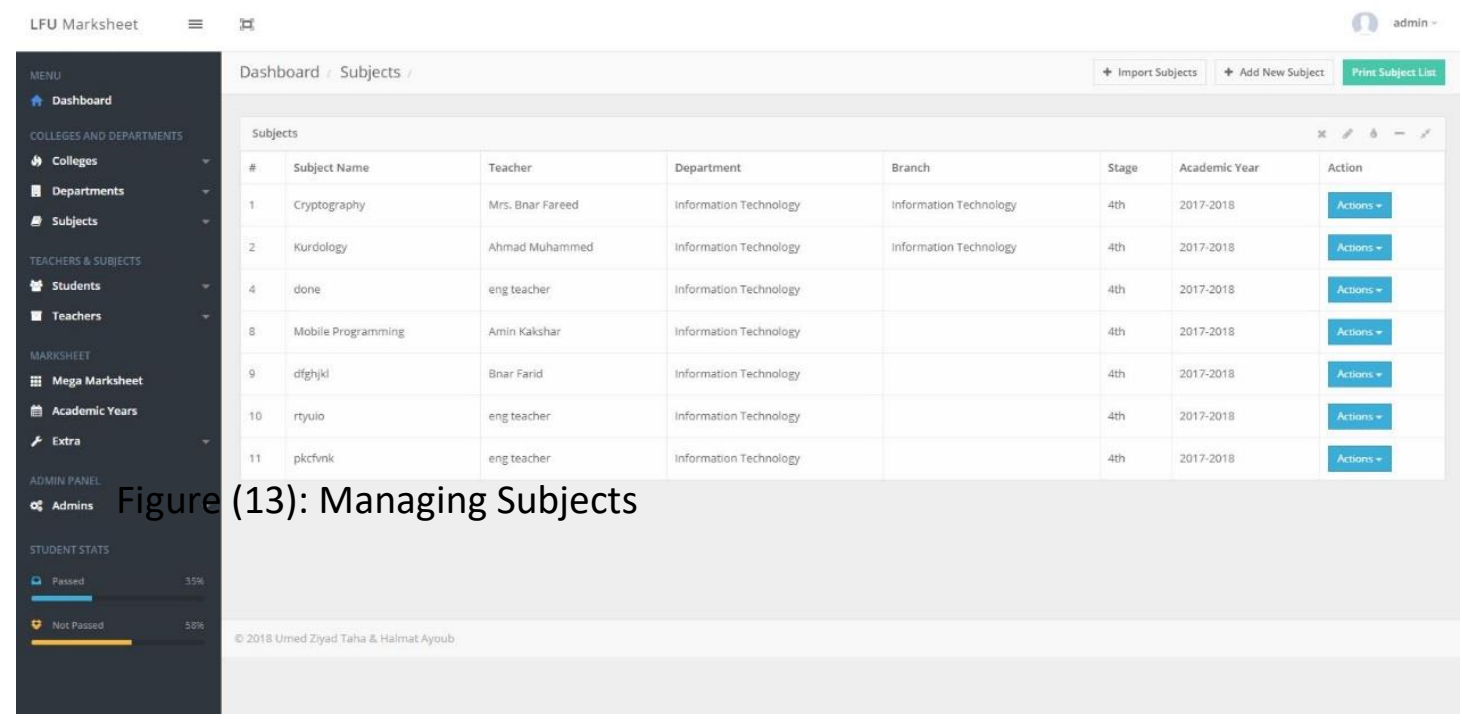




\section{QALAAI ZANIST SCIENTIFIC JOURNAL}

A Scientific Quarterly Refereed Journal Issued by Lebanese French University - Erbil, Kurdistan,

$$
\text { Iraq }
$$

Vol. ( 3 ), Issue ( 4 ), Fall 2018

ISSN 2518-6566 (Online) - ISSN 2518-6558 (Print)

Figure 14: Adding New Subject

\section{Students}

The Manager can add, edit, delete, and manage single or multiple students and import students from Excel files, as shown in Figure (15). Figure (16) shows the list of students and Figure (17) shows how a single student is added.
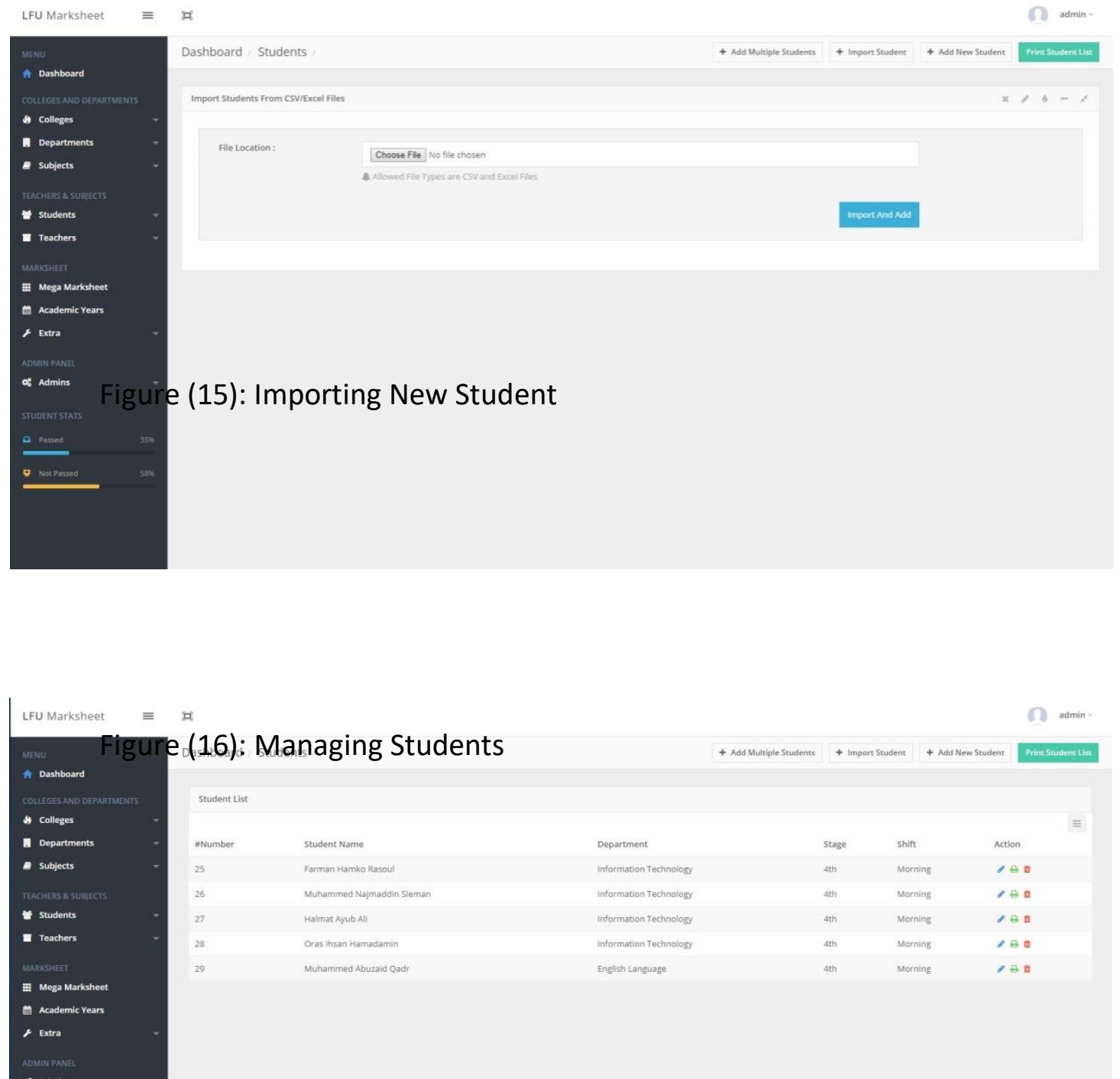
Figure (17): Adding New Student

\section{Curves}

In this system, we have two types of curve (horizontal and vertical). The vertical curve is given by manager for every student under an selected subject, as shown in Figure (18). The horizontal curve includes only those students whose status will be changed from Fail to Pass, as shown in Figure (19). 
Figure (18): Horizontal Curves

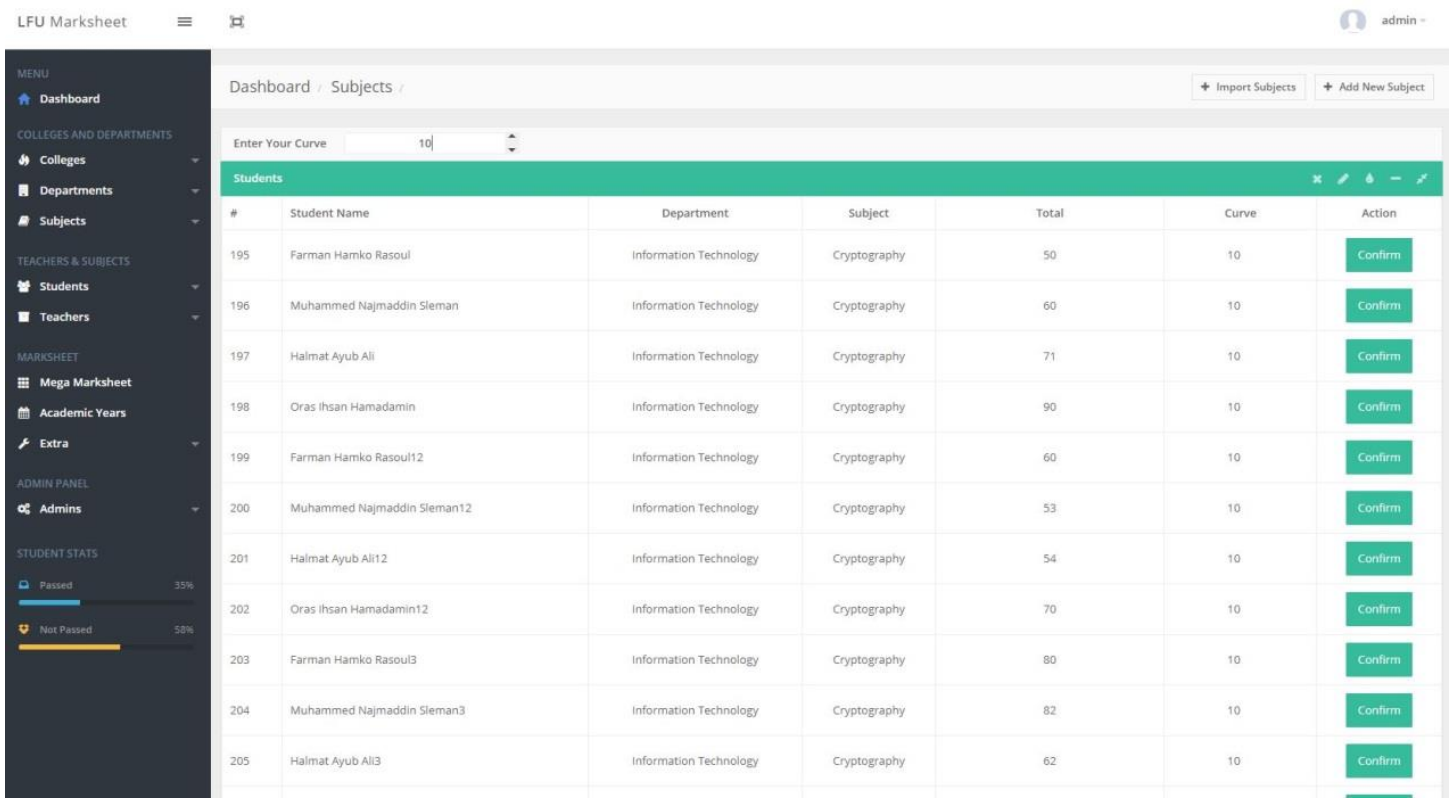

Figure (19): Vertical Curves

\section{Mega Sheet}

The mega sheet consists of marks for every student in each stage arranged in order and can be exported in Excel file or printed out. Figure (20) shows how the Manager can view or select a Mega Sheet for each stage; Figure (21) shows the Mega Sheet result. 


\section{QALAAI ZANIST SCIENTIFIC JOURNAL}

A Scientific Quarterly Refereed Journal Issued by Lebanese French University - Erbil, Kurdistan, Iraq

LF U

Vol. ( 3 ), Issue ( 4 ), Fall 2018

ISSN 2518-6566 (Online) - ISSN 2518-6558 (Print)

Figure (20): Mega Sheet

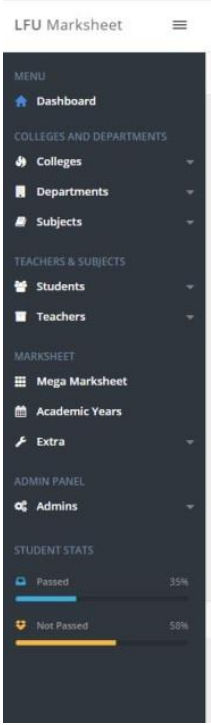

म'

Dashboard / Mega Dashboard

subjects
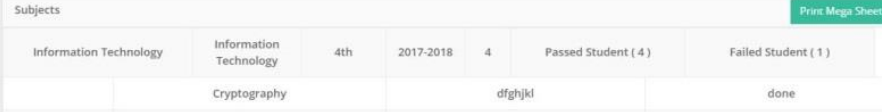

4. Students $40 \% 60 \% 600 \%$ Grade M- $10 \%$
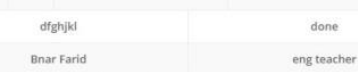

Kurdology

25 Farman

Muhammed
Najmaddin
5 teman

Halmat
Ayub All

Oras insan

\begin{tabular}{|l|l|l|l|}
\hline & VERY \\
\hline
\end{tabular}

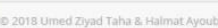

Figure 21 Mega Sheet Result

5. Users \& Permissions 


\section{QALAAI ZANIST SCIENTIFIC JOURNAL}

A Scientific Quarterly Refereed Journal Issued by Lebanese French University - Erbil, Kurdistan, Iraq

LF U

Vol. ( 3 ), Issue ( 4 ), Fall 2018

ISSN 2518-6566 (Online) - ISSN 2518-6558 (Print)

There are three types of users in this system who can access and edit data through permission given to each. The arrangement of user levels are shown below:

- Administrator: Has full access to all departments and colleges.

- Department Manager: Has limited access to specific departments.

- Viewer: Views student marks but does not have permission to edit them.

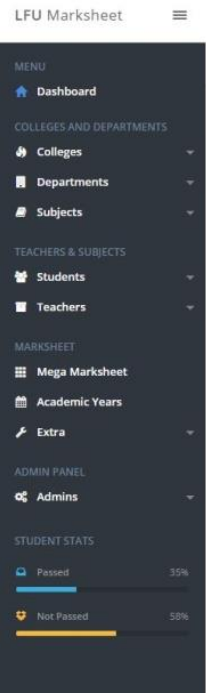

Figure (22): Managing Users 


\section{QALAAI ZANIST SCIENTIFIC JOURNAL}

A Scientific Quarterly Refereed Journal Issued by Lebanese French University - Erbil, Kurdistan, Iraq

Figure (23): Adding New Users

\section{Conclusions}

This attractive application designed for the Lebanese French University will provide information on how to manage grades or information of students smoothly. The implemented application will offer distinct advantages more than those of the systems used presently. The most notable features are its userfriendliness and highly beneficial outputs. The users will greatly benefit from this system. 


\section{References}

[1] Ayo, C. K., Akinyemi, I. O., Adebiyi, A. A., \& Ekong, U. O. (2007). The prospects of e-examination implementation in Nigeria. Turkish Online Journal of Distance Education-TOJDE, 8(4), 125-134.

[2] Andreatos, A., \& Doukas, N. (2006, July). e-Xaminer: Electronic Examination System. In Proceedings of the 3rd WSEAS/IASME International Conference on Engineering Education, Vouliagmeni, Athens, Greece.

[3] Visscher, A. J. (1996a). Information technology in educational management as an emerging discipline. International Journal of Educational Research, 25 (4), 291-296.

[4] Carnoy, M. (2004). ICT in education: Possibilities and challenges. Inaugural lecture of the Universitat Oberta de Catalunya (UOC) 2004-2005 Academic Year, Barcelona.

[5] Visscher, A. J. (1996b). A fundamental methodology for designing management information systems for schools. Journal of Research on Computing in Education, 27 (2), 231-249.

[6] Gurr, D. (2000). How information and communication technology is changing the work of principals. Paper presented at the International Congress of School Effectiveness and Improvement, Hong Kong, January 48. Available at: http://www.ied.edu.hk/cric/ic2000/s9list.htm

[7] Telem, M., \& Buvitski, T. (1995).The potential impact of information technology on the high school principal: a preliminary exploration, Journal of Research on Computing in Education, 27 (3), 281-297.

[8] Telem, M. (1999). A case of the impact of school administration computerization on the department head's role. Journal of Research on Computing in Education, 31 (4), 385-401.

[9] Bober, M. (2001). School information systems and their effect on school operations and culture. Journal of Research on Technology in Education, 33 (5), 1-11.

[10] Li, Q., \& Chen, Y. L. (2009). Entity-relationship diagram. In Modeling and Analysis of Enterprise and Information Systems(pp. 125-139). Springer, Berlin, Heidelberg.

[11] Rumbaugh, J., Jacobson, I., \& Booch, G. (2004). Unified modeling language reference manual, the. Pearson Higher Education. 
[12] Li, Q., \& Chen, Y. L. (2009). Data flow diagram. In Modeling and Analysis of Enterprise and Information Systems (pp. 85-97). Springer, Berlin, Heidelberg.

[13] PHP Group. (2007). PHP Hypertext Preprocessor (2008). URL http://www. php. net.

[14] Collins, M. J. (2017). Hypertext Markup Language. In Pro HTML5 with CSS, JavaScript, and Multimedia (pp. 3-14). Apress, Berkeley, CA.

[15] Lie, H. W., Bos, B., Lilley, C., \& Jacobs, I. (2005). Cascading style sheets (pp. 243-247). Pearson India.

[16] Welling, L., \& Thomson, L. (2003). PHP and MySQL Web development. Sams Publishing.

[17] Bosc, P., Lietard, L., \& Pivert, O. (1994, September). Soft querying, a new feature for database management systems. In International Conference on Database and Expert Systems Applications (pp. 631-640). Springer, Berlin, Heidelberg.

[18] Fielding, R. T., \& Kaiser, G. (1997). The Apache HTTP server project. IEEE Internet Computing, (4), 88-90.

\section{الملخص}

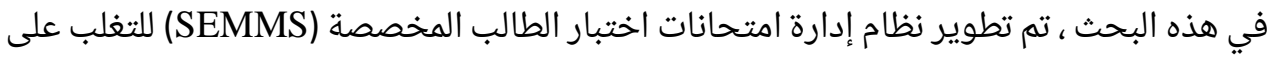

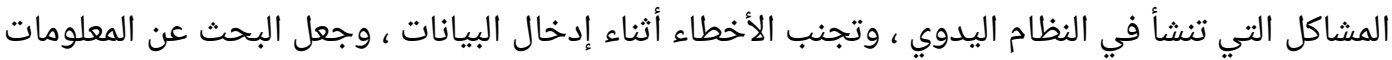

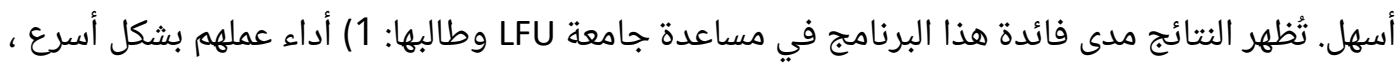

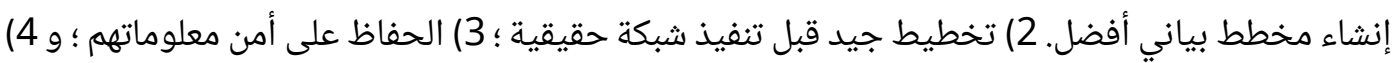

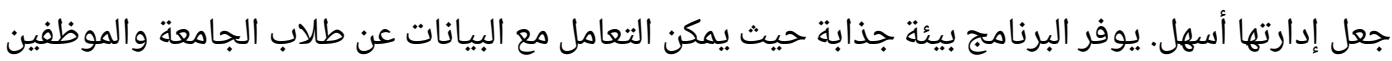
يمكن التعامل معها بسهولة. 


\section{QALAAI ZANIST SCIENTIFIC JOURNAL}

A Scientific Quarterly Refereed Journal Issued by Lebanese French University - Erbil, Kurdistan, Iraq

LF U

Vol. ( 3 ), Issue ( 4 ), Fall 2018

ISSN 2518-6566 (Online) - ISSN 2518-6558 (Print)

لهم تويّزينهوهيدا, گَشه به سيستهمى بهريّوهبردنى تاقيكردنهوهكانى قوتابى (SEMMS) كه تايبهته به جارهسهركردن ئهو كيشانهى كه له سيستهمى دهستى دهكويّت يِيدرا, ههر وهها دوركهوتنهوه له ههلّكان له كاتى توّماركردنى داتاكان , ههر وهها كهران به دوايى زانياريهكان ئاسانتر دهكات , روون دهبيتهوه له دهر ئهنجامهكان سوودى ئهو يروگرامه بو يارمهتى دانى قوتابيانى زانكو LFU : 1) به خيّرايى كارهكانييان جى به جی دهكريّت, دروست كردنى هيّلكارى گونجاوتره 2) بوّ يّلان دانانى باشتر ييّش دروست

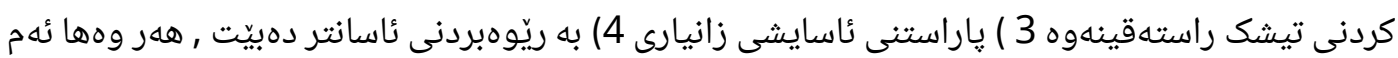
يروگرامه زينكه يه سهى سهرنج راكيشى دروست دهكات له مامهله كردنى له گهل داتاكان كه سهر به قوتابيانى

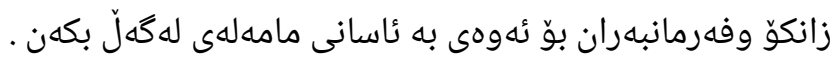

